\title{
Neurofibromatosis Type 1 and Pregnancy: About A Case and Review of the Literature
}

\author{
M. Benayada ${ }^{*}$, N. Chmichi, A. Bennani, A. Lakhdar, N. Zeraidi, A. Kharbach
}

Department of Gynecology-Obstetrics and Endoscopy, Maternity Souissi, University Center IBN SINA, University Mohammed 5, Rabat, Morocco

DOI: $10.36347 /$ sjams.2020.v08i09.017

| Received: 03.09.2020 | Accepted: 10.09.2020 | Published: 17.09.2020

*Corresponding author: Mariyam Benayada

Abstract

A pregnancy is classified as high risk when the life of the mother or the fetus becomes fragile due to its association with certain diseases. Many health problems can be experienced in women before pregnancy, during and after pregnancy. Some health problems can also start in early adolescence with very mild clinical signs, but during pregnancy due to hormonal changes that may occur, lead to an intensification of the disease. We report the management of a 28-year-old woman with neurofibromatosis 1 (NF1). This study highlights the various complications related to $\mathrm{Nf1}$ and its impact on pregnancy.

Keywords: Neurofibromatosis type 1, Pregnancy, Vascular complication.

Copyright @ 2020: This is an open-access article distributed under the terms of the Creative Commons Attribution license which permits unrestricted use, distribution, and reproduction in any medium for non-commercial use (NonCommercial, or CC-BY-NC) provided the original author and source are credited.

\section{INTRODUCTION}

Neurofibromatosis type 1 is the most common autosomal dominant genetic disease with an incidence of 1 in 3000 to 5000 births worldwide [1,2]. It was first described in 1793, then better documented in 1882 by von Recklinghausen, hence its name vonRecklinghausen disease or neurofibromatosis type 1 $[3,4]$. It is inherited in an autosomal dominant manner and is caused by one of several possible mutations on chromosome 17 (17q11.2). The gene is a tumor suppressor, encoding the protein neurofibroma, and its loss of function results in abnormal cell proliferation and tumor development. This increase takes place especially during periods of rapid growth, such as infancy, puberty, and pregnancy. The diagnosis of NF1 is made when at least two of the following signs are encountered: Six Café au lait spots, axillary or inguinal lentigines, two cutaneous neurofibromas or one plexiform neurofibroma, two Lisch nodules (iris harmartomas), a specific radiological lesion (sphenoid dysplasia, pseudarthrosis, cortical dysplasia of long bones), optic pathway glioma and a first degree relative affected [7, 8]. The association of this disease with pregnancy is rare but can be serious. Through a case where NF1 and pregnancy are associated, we present the analysis of the various maternal-fetal repercussions and the management methods for this risky pregnancy.

\section{CaSe Report}

A 28 years old pregnant patient, Para 3 Gravida 2, her first pregnancy was a first trimester miscarriage, the second was a vaginal delivery 3 years ago, a family history of a mother diagnosed with NF1, admitted to the emergency room for the onset of labor at 38 weeks according to her LMP. The patient has reported during her fist pregnancy, the appearance of dozens of papules and nodules which lead to the diagnosis of type 1 neurofibromatosis. During this pregnancy, they have progressively increased in number and size from the last time she noticed them. This pregnancy was uncomplicated with all the laborite test within the normal limits, except the appearance of a mild scoliosis. The physical examination revealed caféau-lait macula and neurofibromas located mainly on the abdomen, neck and thorax, blood pressure at 15/10 without neurosensory signs, negative urinalysis, fetal heartbeat heard, no uterine contractions, uterine height at $28 \mathrm{~cm}$. the vaginal examination performed and the cervix was found to be 50 percent effaced and $1 \mathrm{~cm}$ dilated with fetal head poorly applied to the cervix and intact membranes. Obstetrical ultrasound revealed a singleton pregnancy with normal cardiac activity, the biometry obtained was corresponding to 34 weeks of pregnancy with oligohydramnios and pathological fetal Doppler. The patient was commenced on continuous CTG monitoring which showed decelerations. A blood sample was taken immediately from the patient for a $\mathrm{CBC}$, coagulation test, liver and renal function blood test. The patient was given an antihypertensive 
treatment and received a dose of betamethasone for lung maturation. Caesarean section was indicated immediately for acute fetal distress and gestational hypertension, which allowed cephalic extraction of a male newborn, Apgar score of 6/7/8 and a birth weight of $2100 \mathrm{~g}$. The newborn was then hospitalized in neonatal care and showed good improvement. The postoperative period was unremarkable, she left the hospital after 4 days with adequate advice and recommendations (Figure $1 \& 2$ )

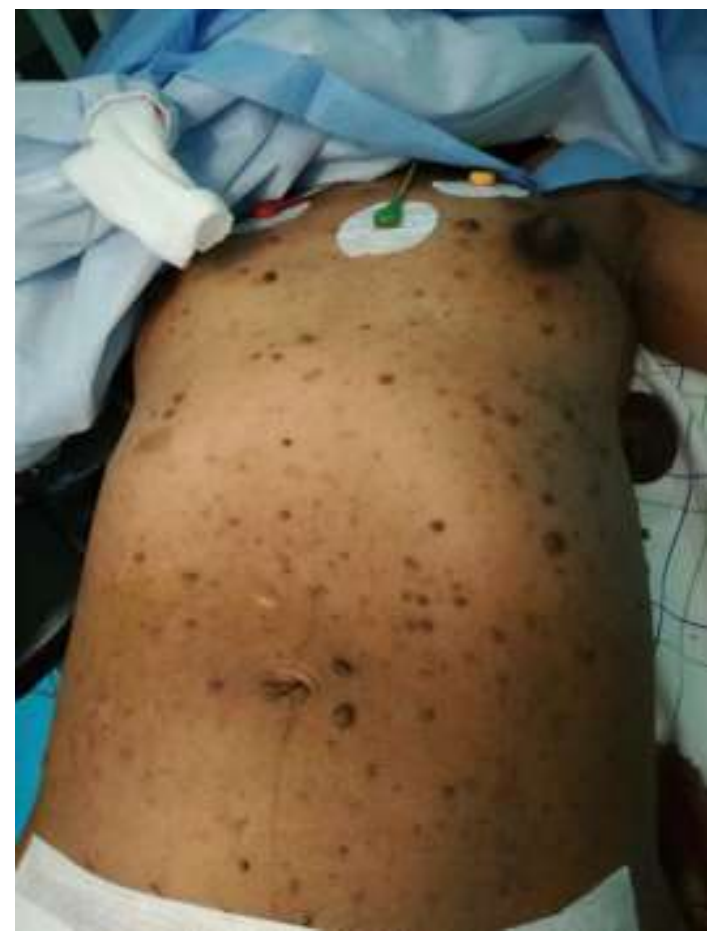

Fig-1: The multiples spots and nodules in the chest and abdomen

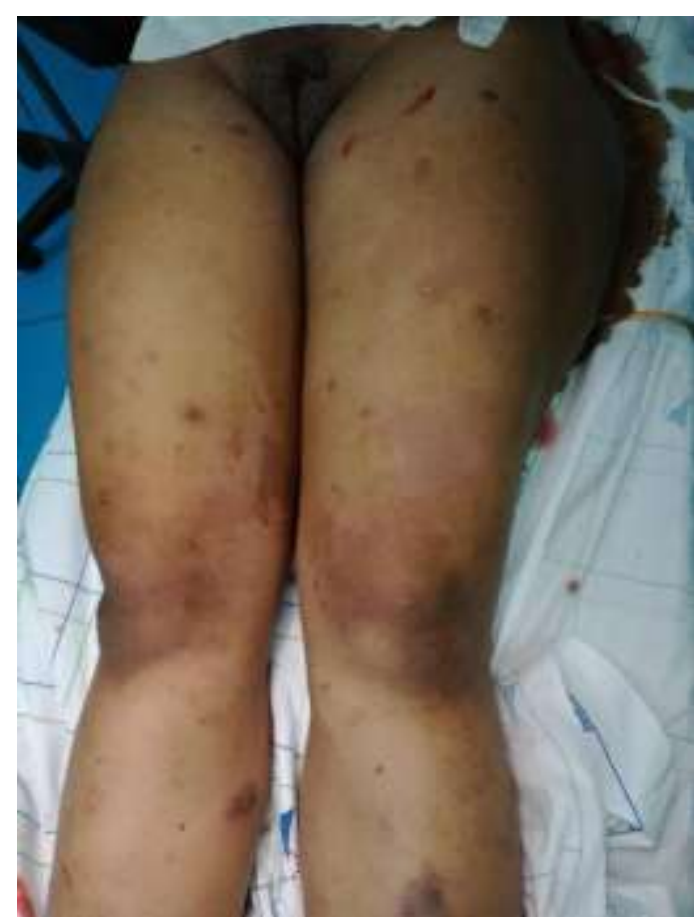

Fig-2: Multiple spots and nodules on the vulva and on the thighs

\section{DISCUSSION}

Neurofibromatosis 1 (NF1) is one of the most common genetic diseases. It is an autosomal dominant condition. It is characterized by an extreme variability of its clinical expression which is also found within the same family. The clinical picture of NF1 most often associates multiple café-au-lait spots, axillary and inguinal lentigines, cutaneous neurofibromas and Lisch nodules.

Neurofibromatosis is a genetic disease associated with increased maternal morbidity during pregnancy but has no impact on increased maternal mortality. Data on the course of pregnancy in women with NF1 are scarce. They are, however, necessary to provide reliable information to women with a Nf1 and wishing to have a child, but also to the doctors who have to follow these women during their pregnancy. There are two types of publications on the subject: reports on single cases which just provide a range of possible complications, without guarantee of completeness, but also series. These retrospective studies, sometimes involving less than 10 observations, will not escape a certain bias. Their data mainly concerns the influence of $\mathrm{Nf1}$ on pregnancy rather than that of pregnancy on the Nf1 of future mothers. They provide an idea of the relative frequencies of complications of pregnancy within $\mathrm{Nf1}$ without comparing them, in general, to those of pregnancies outside this context. Two publications are of particular interest: That of Dugoff and sujansky by the large number of cases studied: 247 pregnancies in 105 women, and those of Segal et al., this is the only comparative series covering 8 cases and 67 witnesses. The other publications relate to more or less important series $[5,6]$.

\section{Influence of pregnancy on NF1}

Is frequently mentioned in general reviews and books devoted to NF1. The study by Dogoff et al. Reports that out of 105 women, $60 \%$ noted the appearance of new neurofibromas, $52 \%$ saw some of their old neurofibromas increase in size and 33\% reported a decrease in the volume of these neurofibromas after childbirth [5, 9, 13, 14]. The extent and reversibility of these changes are unknown. They can involve their neurofibromas other than cutaneous, pelvic, and thus constitute obstructions dystociques.

\section{Induction of Vascular Complications}

The vessels of patients with NF1 are likely to contain structural abnormalities such as aneurysms, thinning of the vascular wall, infiltration of the wall by neurofibromatosis tissue. Pregnancy can cause decompensation of this weakened area by the increase in circulating blood volume and by the hormonal influence on the vascular wall. Cases of arterial ruptures have been reported [20]. 


\section{Renovascular Hypertension}

Renal artery stenosis leading to high blood pressure is a known complication of NF1. It can occur during pregnancy. The authors note that renovascular hypertension occurs with a frequency 7 times greater before the age of 18 than in adults, conclude that pregnancy is responsible for the decompensation of this pathology and suggest an exploration in the event of hypertension before the design [21].

\section{Pheochromocytoma}

This rare tumor occurs with increased frequency during NF1. A review of the literature between 1966 and 1999 estimates this frequency from 0.1 to $5.7 \%$ in $1 \%$ of cases the pheochromocytoma was associated with pregnancy.

\section{Malignant Tumor of the Nerve Sheaths}

The occurrence of malignant nerve sheath tumors has been reported during pregnancy without being able to attribute pregnancy to an inducing role $[10,11]$.

\section{Influence of NF1 on pregnancy:}

Fertility: Fertility does not seem to be affected by NF1 apart from the difficulty of starting a couple.

First trimester spontaneous abortions: In the publication of Dugoff et al., Their frequency was $19.5 \%$ and considered to be in the standard. In that of Weissman, it was $20.7 \%$, considered higher than the expected frequency. The frequency of spontaneous miscarriages is difficult to assess but is probably close to $12 \%$ to $15 \%$ of pregnancies. This number can quadruple after the age of 35 [5, 12].

\section{High Blood Pressure in Pregnancy and Preeclampsia}

Pregnancy hypertension (HTAG) is defined as a PAS> $140 \mathrm{mmhg}$ and / or DBP> $90 \mathrm{mmhg}$, isolated without proteinuria, onset from the 20th week of amenorrhea in the absence of a history. Preeclampsia associates this HTAG with proteinuria $>300 \mathrm{~g} / \mathrm{d}$ or $>2$ crosses. Several publications report cases associated with NF1. In the study by Dugoff et al., Out of 180 completed pregnancies (out of 247 pregnancies in total), there were $7(4 \%)$ preeclampsia and $4(2 \%)$ arterial hypertension of the pregnancy. The authors consider these data to comply with the standard. In the study by Segal et al., Of 8 women with NF1 (13 pregnancies) compared to 65 controls matched for age and parity, the frequency of hypertension in women with NF1 was not statistically different from that of witnesses. Charma et al., Report the follow-up of 10 patients: 7 had hypertension during pregnancy, 1 eclampsia and 4 preeclampsia. In 5 cases of eclampsia and preeclampsia, fetal death was systematic $[5,13,15,16]$.

\section{Intrauterine Growth Retardation}

Is defined by fetal hypotrophy between the 10th percentile for moderate IUGRs and below the $3 \mathrm{rd}$ percentile for severe IUGR. This definition is imprecise and variable depending on the etiologies because IUGR can be harmonious (all measurements) or disharmonious, affecting only part of the fetus. The birth weights are compared to reference curves established from the distribution of the population studied. In the study by Segal et al., IUGR was observed in $46 \%$ of cases versus $8.9 \%$ in controls, this highly significant difference is attributed by the authors to the decrease in uteroplacental perfusion, associated with other abnormalities such as worsening by pregnancy of Constitutional abnormalities of small arteries in NF1. Weissman et al., Report $13 \%$ of IUGR out of 34 observed pregnancies. In contrast, some authors believe that the frequency of IUGR is not increased in NF1 [6, 12, 18, 19].

\section{Premature Delivery}

Is defined by a live birth between 22 and 37 weeks. In the large series by Dugoff et al., No preterm delivery was noted. However, in the comparative series by Segal et al., The frequency of this complication was significantly more frequent than in the control series: $23 \%$ versus $1.5 \%[5,6]$.

\section{Cesarean Section}

According to the series by Dugoff et al., Cesarean section is the only pregnancy event whose frequency, $36 \%$ of 182 pregnancies completed, is considered excessive compared to the frequency generally observed $[5,17]$.

\section{CONCLUSION}

NF1 was associated with an increase in maternal morbidity during pregnancy (including hypertensive and cerebrovascular complications), but not an increase in maternal mortality. Obstetricians should be aware of the potential for increased prenatal and peripartum complications in women with NF1.

\section{REFERENCES}

1. Gorlin RJ, Cohen MM, Levin LF. Syndromes of the head and neck. Oxford: Oxford University Press; 1990; 353-416.

2. Huson SM, Compston DA, Harper PS. Une étude génétique de la neurofibromatose de von Recklinghausen dans le sud-est du Pays de Galles. II. Lignes directrices pour le conseil génétique. J Med Genet. 1989; 26: 712 21. Disponible: http://www.ncbi.nlm.nih.gov/pub med/2511319 pmid: 2511319

3. Bekisz O, Darimont F, Rompen EH. Diffuse but unilateral gingival enlargement associated with von Recklinghausen neurofibromatosis: A case report. J Clin Periodontol. 2000; 27:361-5.

4. Hillier JC, Moskovic E. The soft tissue manifestations of neurofibromatosis type 1. Clin Radiol. 2005; 60:960-7. 
5. Dugoff L, Sujansky E. Neurofibromatosis type 1 and pregnancy. Am J Med Gen Part A. 1996; 66(1):7-10.

6. Segal D, Holcberg G, Sapir O, Sheiner E, Mazor M, Katz M. Neurofibromatose pendant la grossesse. Résultat maternel et périnatal. Eur J Obstet Gynecol Reprod Biol, 1999; 84:59-61.

7. Ferner RE, Gutmann DH. Neurofibromatose de type 1 (NF1): diagnostic et prise en charge. Handb Clin Neurol. 2013; 115:939-55.

8. NIH. Déclaration de la conférence sur le développement $\mathrm{du}$ consensus des National Institutes of Health: neurofibromatose. Bethesda, Md, USA, 13-15 juillet 1987. Neurofibromatosis. 1988; 1:172-8.

9. Nguyen R, Dombi E, Widemann BC, Solomon J, Fuensterer C, Kluwe L, Friedman JM, Mautner VF. Growth dynamics of plexiform neurofibromas: a retrospective cohort study of 201 patients with neurofibromatosis 1. Orphanet journal of rare diseases. 2012 Dec;7(1):1-6.

10. Mautner VF, Brenner W, Fünsterer C, Hagel C, Gawad K, Friedrich RE. Pertinence clinique de la tomographie par émission de positons et de l'imagerie par résonance magnétique dans la progression du neurofibrome plexiforme interne dans la NF1. Anticancer Res. 2007; 27: 181922. Disponible: http://www.ncbi.nlm.nih.gov/pub med/17649778 pmid: 17649778

11. Cai W, Kassarjian A, Bredella MA, Harris GJ, Yoshida H, Mautner VF. Charge tumorale chez les patients atteints de neurofibromatose de types 1 et 2 et de schwannomatose: détermination sur des images RM du corps entier. Radiologie. 2009; 250: 665-73.

12. 12-.Weissman A, Jakobi P, Zaidise I, Drugan A. Neurofibromatose et grossesse. Une mise à jour. J Reprod Med. 1993; 38: 8906. Disponible: http://www.ncbi.nlm.nih.gov/pubm ed/8277488 pmid: 8277488

13. Sharma JB, Gulati N, Malik S. Maternal and perinatal complications in neurofibromatosis during pregnancy. Int J Gynecol Obstet. 1991; $34: 221-227$.
14. Terry AR, Barker FG, Leffert L, Bateman BT, Souter I, Plotkin SR. Neurofibromatose de type 1 et complications de la grossesse: une étude basée sur la population. Suis J Obstet Gynecol. 2013; 209:46.e1-8.

15. Hagymasy L, Toth M, Szucs N, Rigo Jr J. Neurofibromatose de type 1 avec hypertension rénovasculaire associée à la grossesse et syndrome d'hémolyse, élévation des enzymes hépatiques et faible taux de plaquettes. Am J Obstet Gynecol. 1998; 179:272-274.

16. Agarwal U, Dahiya P, Sangwan K. Neurofibromatose d'apparition récente compliquant l'éclampsie avec décès maternel: un rapport de cas Arc Gynecol Obstet, 2003; 268:241242.

17. Declercq E, Menacker F, Macdorman M. Profils de risque maternel et taux de césarienne primaire aux États-Unis, 1991-2002. Am J Public Health. 2006; 96:867-872.

18. Agarwal U, Dahiya P, Sangwan K. Neurofibromatose d'apparition récente compliquant l'éclampsie avec décès maternel: un rapport de cas. Arc Gynecol Obstet. 2003; 268:241-242.

19. Hagymasy L, Toth M, Szucs N, Rigo Jr J. Neurofibromatose de type 1 avec hypertension rénovasculaire associée à la grossesse et syndrome d'hémolyse, élévation des enzymes hépatiques et faible taux de plaquettes. Am J Obstet Gynecol. 1998; 179:272-274.

20. Friedman JM, Arbiser J, Epstein JA, Gutmann DH, Huot SJ, Lin AE, Mcmanus B, Korf BR. Cardiovascular disease in neurofibromatosis 1: report of the NF1 Cardiovascular Task Force. Genetics in Medicine. 2002 May;4(3):105-11.

21. Oderich GS, Sullivan TM, Bower TC, Gloviczki P, Miller DV, Babovic-Vuksanovic D, Macedo TA, Stanson A. Vascular abnormalities in patients with neurofibromatosis syndrome type I: clinical spectrum, management, and results. Journal of vascular surgery. 2007 Sep 1;46(3):475-84. 